Possibly, in a few instances, the ridges on the hill-slopes may be due to outcropping strata, and others might suggest terrace-cultivation; but there seems ample evidence for the view taken that Neolithic cattle-tracks have survived to this day around certain of our most imposing " camps."

Failing large-scale maps, a sketch-plan of the earthworks noticed would have made the description even more illuminating; but the only matters of complaint are that the book is all too short, and that the paper selected to throw up the detail of the photographs is as chalky as the Downs they illustrate so pleasantly.

\section{HENRY BENEDICT MEDLICOTT, F.R.S.}

$\mathrm{O}^{\mathrm{N}}$ April 6 there passed away one of the few survivors amongst the small body of men who laid the foundations of Indian geology. Despite much excellent work, chiefly by non-professional men, very little was really known of the geology of India, and especially of Peninsular India, before the middle of the nineteenth century, and as one instance amongst many, the Vindhyans, now believed to be Archæan, were still classed with Gondwana PermoCarboniferous strata, and both were regarded as of Jurassic age. A comparison of Dr. Carter's "Summary of the Geology of India between the Ganges, the Indus and Cape Comorin," published in I853, with the "Manual of the Geology of India," issued in 1879 , will show the great improvement that took place in the meantime in our knowledge of the country

In this change none had a larger share than Henry Benedict Medlicott. Born in Loughrea, county Galway, he was the second of three sons of the Rev. Samuel Medlicott, rector of Loughrea, and of Charlotte, the daughter of Colonel H. B. Dolphin, C.B. All three sons were men of great intellectual capacity and of marked originality. The eldest, J. G. Medlicott, became a member of the Geological Survey of India before his brother joined; he was subsequently in the Indian Educational Service, and died in 1866. The third brother, Samuel, was a clergyman, who has also been dead several years. The subject of the present memoir was educated at Trinity College, Dublin, and, after taking his degree, was for a short time on the staff, first of the Irish, then of the English Geological Survey. In the spring of 1853 he joined the Geological Survey of India under the late Dr. Thomas Oldham, but was almost immediately appointed professor of geology at the Roorkee College of Civil Engineering, an appointment which he held until 1862, when, on some additions being made to the staff, he re-joined the Geological Survey of India, and was made deputy superintendent for Bengal.

But during his tenure of the Roorkee post he spent part of the year surveying for the Geological Survey, and in his first season's work he and his brother made a primary step towards the elucidation of Indian geological history by separating the ancient Vindhyans north of the Son and Nerbudda Rivers from the Indian Coal-measures and their allies to the southward. In subsequent years, whilst his brother mapped the last named strata, he surveyed the older Vindhyans and their associates, and to him we owe our first recognition of the Bijawur and other ancient rocks between the old gneissic formation and the Vindhyans. In other years he explored the Himalayas, and the ranges at their base, between the Ganges and the Ravi, and he drew up the description of the older unfossiliferous beds of the mountains, and of the Tertiary and other strata fringing their base, which was published in the third volume of the Indian Memoirs. This contains a sketch of the history of the Himalayas which has been generally accepted ever since.

After returning to the survey in 1862 (he always protested that he really had remained a member of the staff throughout), he examined in successive years the greater part of northern India. Various tracts of the Himalayas from the Punjab to Assam, the Assam valley and the hill ranges south of it, and, in the Peninsula, Rajputana, Nimar, the Nerbudda valley and Satpura ranges, Bundelkhand, South Rewah, Chhatisgarh and Sambalpur, Chota Nagpore, Hazaribagh, and Behar were visited and reported upon in turn.

Dr. Oldham retired in 1876 , and Mr. Medlicott succeeded him as superintendent, a title subsequently changed to director of the survey. The first work undertaken by him as superintendent was a general account of Indian geology. This had long been urgent, and would probably have been written by Dr. Oldham but for failing health. The "Manual of the Geology of India " was published in 1879 , and a very large portion, including the account of the Azoic rocks from gneiss to Vindhyans (which between them cover the greater part of the Indian peninsula), and of the geology of the Himalayas and sub-Himalayas, in fact, nearly half the entire work, was written by Mr. Medlicott himself. In many ways a great impulse was given to survey work by the new superintendent. As regards publication alone, the volumes of the Records from 1877 are doubled in bulk when compared with previous issues, and these volumes, containing accounts of recent geological observations, both economical and scientific, represent the actual field work of the survey to a larger extent than the longer memoirs and palæontologia.

Throughout his career as head of the survey $\mathrm{Mr}$. Medlicott adopted a most liberal policy of publication. He allowed his staff to report on their own work freely, and whilst assisting them in every way, both in the field and in the study, he never took any of the credit of their work. Not only did he welcome reports from the geologists of the survey, but he published, whenever possible, contributions from independent observers. In this manner he secured the valuable assistance of the late General McMahon, the whole of whose most important observations on the physical history of the Himalayas appeared in the Records of the Geological Survey of India.

Modest and retiring, he was nevertheless a man of high courage and independence. One trait of this was shown in the Indian Mutiny, when, with one companion, despite the mutiny of the guard that should have accompanied them, he saved the lives of a Christian family who had fallen into the hands of the rebels, a most gallant action, the account of which is due to Colonel Baird Smith, the head of Roorkee College and the commanding officer. After retiring from the Indian Survey in 1887 , he lived very quietly at Clifton, devoting himself to philosophical problems. He published a couple of short pamphlets on "Agnosticism and Faith" in I888, and on "The Evolution of Mind in Man," but a larger work on which he was engaged is, it must be feared, incomplete. A strain caused by bicycling led to serious heart symptoms some years ago, and although a partial recovery was made, a relapse about a year since reduced him so much that it was not surprising to hear that he passed quietly away on April 6, whilst seated in his study.

Mr. Medlicott became a Fellow of the Geological Society as long since as 1856 , and in 1888 , on his retirement from India, he received the Wollaston

NO. 852, V')L. 7 I ] 
medal. He was elected a Fellow of the Royal Societr in 1877 . He received the military medal for his services in the Mutiny. He was also a Fellow of Calcutta University, and from 1879 to $188 \mathrm{r}$ he was president of the Asiatic Society of Bengal.

W. T. B.

\section{NOTES.}

THE report on the natural history collections made in the Antarctic regions by the Discovery Expedition, to be published by the trustees of the British Museum, and edited by Prof. F. Ray Lankester, F.R.S., promises to be of particular interest and importance. The working out of the collections has been entrusted to nearly fifty naturalists, each of whom will deal with material in which he is specially interested. Inquiries concerning the zoological and botanical collections should be addressed to $\mathrm{Mr}$. F. Jeffrey Bell, British Museun (Natural History), Cromwell Road, London, S.W.

THE council of the Institution of Civil Engineers has made the following awards for papers read and discussed before the institution during the past session:-Telford gold medals to Lord Brassey, K.C.B., and Mr. C. S. R. Palmer; a George Stephenson gold medal to $\mathrm{Mr}$. Lyonel E. Clark; a Watt gold medal to Mr. J. F. C. Snell; Telford premiums to Messrs. L. F. Vernon-Harcourt, R. W. Allen, and Wm. Marriott; a Crampton prize to Mr. A. Wood-Hill, and the Manby premium to Mr. E. D. Pain. The presentation of these awards, together with those for papers which have not been subject to discussion and will be announced later, will take place at the in augural meeting of next session. Sir Alexander Binnie has been elected president of the institution in succession to Sir Guilford Molesworth, K.C.I.E.

Mr. W. E. CoOKE, Government astronomer for Western Australia, writes to us from the observatory at Perth to direct attention to an unusual seismic disturbance in that place. During March 5 there were three marked earthquakes in the space of a few hours, and these reached their maxima at $16 \mathrm{~h} .25 .8 \mathrm{~m}$., $19 \mathrm{~h} .0 .1 \mathrm{~m}$. , and $13 \mathrm{~h} .42 .6 \mathrm{~m}$. The times are given in Greenwich civil time. Each maximum was preceded by tremors from fifteen to twenty minutes earlier, and by a large wave from ten to fifteen minutes before the maximum. It is noteworthy that the transit circle was displaced considerably in both level and azimuth. Another earth tremor, the greatest yet registered on the Milne seismograph at Perth, occurred on March 19. There were no preliminary tremors; the disturbance proper commenced abruptly, and reached a maximum in $19.6 \mathrm{~m}$.

THE workers at the Port Erin Biological Station during this spring vacation include Prof. B. Moore, Dr. H. E. Roaf, and Mr. B. Whitley (all from the biochemical department of the University of Liverpool), Mr. J. A. Dell and Mr. E. Standing (from the University of Leeds), Prof. Herdman, Mr. W. Dakin, and Mr. W. A. Gunn (from the University of Liverpool), and Mr. Chadwick, the curator. Prof. Moore and his party are investigating the changes produced in the growth of embryos by alterations in the constitution of the sea-water and other conditions of the environment. The other workers are engaged on various lines of zoological research. The fish-hatching is now going on rapidly, and more than three millions of plaice fry have already been turned into the sea this month. The parent plaice in the spawning pond were evidently about a fortnight earlier in reproducing this season than last, as the first fertilised eggs were obtained on February 14, and in large quantity, as against March 3 in 1904.

NO. [ 852 , VOL. 7 I]
IT is proposed to send out a special series of telegraphic time signals beginning at II.55 p.m., United States Eastern Standard Time (mean time of the $75^{\text {th }}$ meridian west from Greenwich), on May 3, and ending at midnight, according to the plan followed daily at noon. These special time signals will be sent out by request of the American Railway Association, with the approval of the Secretary of the Navy, in honour of the International Railway Congress, which is to meet in the capital of the United States on the following day. It is hoped that the principal observatories of the world will make efforts to receive and time these signals accurately, and reports of such observations may be made at once, without expense, through the courtesy of the various telegraph and cable companies. This was done in the case of the New Year's Eve time signals from the United States Naval Observatory, which are reported to have reached the Toronto Observatory in $0.00 \mathrm{~s}$.; Lick Observatory, $0.05 \mathrm{~s}$. City of Mexico, o.IIs.; Manila, 0.37s.; Greenwich, 1.33s.; Sydney, Australia, 2.25s.; Wellington, N.Z., 4.00s.; and Cordoba, Argentina, $7 \cdot 7 \mathrm{~s}$. From the rapidity and accuracy with which these time signals are transmitted over connecting land lines, as a result of long experience in transmitting the daily noon signals, it seems very probable, if the telegraph companies will take especial care in their transmission and not interpose any secondary clocks or human relays, that they may serve to give fairly accurate determinations of longitude at any telegraph station on the American continent where they can be noted exactly and compared with accurate local time.

IT was decided in the Chancery Division of the High Court on April ig that the public has not the right of free access to Stonehenge. The question of free access was raised by an action in which the Attorney-General claimed an order against Sir Edmund Antrobus to remove the fencing which now encloses Stonehenge, and an injunction to restrain him from erecting any such fencing. The claim was based on two grounds:-(I) that Stonehenge is a national monument of great interest and is subject to a trust for its free user by the public; (2) that there are public roads running up to and through Stonehenge, and that those roads have been blocked by the defendant's fencing. Mr. Justice Farwell, who heard the action, decided that both these claims were untenable; and he therefore dismissed the action, with costs. In concluding this judgment, his Lordship is reported by the Times to have remarked :- "I hold that the access to the circle was incident only to the permission to visit and inspect the stones, and was, therefore, permissive only, and, further, that the tracks to the circle are not thoroughfares, but lead only to the circle, where the public have no right without permission, and, therefore, are not public ways. The action accordingly fails, and ought never to have been brought. It is plain that the vicinity of the camp and the consequent increase of visitors compelled the defendant to protect the stones if they were to be preserved; and he has done nothing more than is necessary for such protection. I desire to give the relators credit for wishing only to preserve this unique relic of a former age for the benefit of the public, but I fail to appreciate their method of attaining this. The first claim to dispossess the defendant of his property is simply extravagant, so much so that, although not technically abandoned, no serious argument was addressed to me in support of it. The rest of the claim-for rights of way over the network of tracks shown on the plaintiff's plan-if successful would defeat the relators' object. If these ways were left unfenced and heavy traffic passed through the circle, there 